\title{
The Urgency of Law Number 18 of 2019 concerning Pesantren as an Educational, Da'wah and Community Empowerment in Tegal Regency
}

\author{
Zaki Mubarok \\ Fakultas Syariah dan Ushuludin Institut Agama Islam Bakti Negara (IBN) Tegal \\ \{zakimubarok862@gmail.com\}
}

\begin{abstract}
The existence of Pesantren in the national education system has been confirmed through law number 18 of 2019 concerning Pesantren. Through this law, Pesantren receive affirmation and recognition from the state as educational, da'wah and community empowerment institutions that are characterized by the uniqueness of each Pesantren. Thus, Pesantren education has the same rights and obligations as other education according to their respective levels. Pesantren, both as educational, da'wah and community empowerment institutions, actually operate as instruments in enforcing religious and state orders in the field of humanity. The history and distribution of Pesantren throughout the archipelago with their various characters and uniqueness are State assets which after being integrated into the national education system, must be welcomed by regulations in the local spheres as an effort to implement the concurrent principle of constitutionality. Since the beginning, Pesantren's identity was the love of the country, teaching moderatism at the same time being with the people as an important element in the struggle and filling independence with local wisdom. For this reason, regional regulations that are derivatives of the Pesantren Law and the division of tasks between the central and regional governments in the field of education are urgently compiled to carry out the constitutional mandate of Pesantren at the regional level. Field studies with a qualitative approach show that local regulations on Pesantren are needed at least to strengthen the role of Pesantren in safeguarding State sovereignty amid the increasing number of religious issues as a component of political conflict. This is none other than so far the Pesantren has never been proven to teach its students to fight against the legitimate State. Second, to produce graduates who are ready to work at various career levels. Third, with the integration of vocational education in Pesantren, it can reduce the rate of urbanization by creating creative jobs in the local sphere. This is the true urgency of the Pesantren's humanitarian mission, which has received a legal through the Pesantren Law.
\end{abstract}

Keyword: Pesantren, Humanity dan State

\section{Preliminary}


In 2018 the Ministry of Religion (Kemenag) through the Directorate of Early Education and Islamic Boarding Schools (PD Pontren) at both the Central and Regional levels campaigned for and oversaw the strengthening of Islamic moderation (mainstreaming Islamic moderation) in various spheres of activity. Both education, preaching and community service. What the state should do as historical work is to continue to maintain the historiography of Islamic moderation in Indonesia. Because the history of Islamic moderation in Indonesia cannot be separated from the role of Islamic boarding schools in all their models and forms. According to Zayadi, pesantren have a strategic role in promoting moderate Islam. Therefore, the Ministry of Religion through the Directorate of Early Education and Islamic Boarding Schools has created a flagship program related to Islamic moderation [1]. Of course, this program must get massive support from various parties, both formal institutions and other communities. From the center to the local realm.

Apart from that, the moderation of Islam through Islamic boarding schools should also be strengthened considering the stigma of Islamic boarding schools as educational institutions that are insensitive to current developments. As if Islamic boarding schools are a burden of civilization for the country. This condition is exacerbated by the emergence of terrorism which sporadically accuses Islamic boarding schools of being the party that produces terrorism cadres. In fact, Islamic boarding schools are actually magnum opus of Islamic moderation values that supply peace to this country.

In fact, pesantren is a unique Indonesian Islamic-based educational institution that emphasizes its importance in spreading a culture of peace. Since the beginning of its development, pesantren have been educational institutions that are moderate and accommodating to differences in society [2]. In other words, the existence of pesantren is actually an agent of change for society in the global discourse, it is hoped that it can become a mediating structure to understand problems that arise in society and be able to bridge community empowerment for the realization of common ideals to form civil society. Because pesantren are "friendly" to the community, in the realm of socio-culture, politics, economy, this institution is also able to play a role as a locomotive and a dynamist in monitoring change [3].

Where as pesantren are an integral part of various dimensions of human life. Armed with the lesson references obtained from the yellow book, the pesantren students actualize themselves in various social fields. The doctrine of truth instilled in a typical pesantren with acceptance of different religious thoughts is the strong foundation of moderation it carries. Since in the pesantren, students have been accustomed to studies based on various references. Both in fiqh, siyasah, aqidah and others. To achieve goodness, students have been taught and used to it in a good way too. The habituation method is carried out with competition in good works which is articulated in the form of a positive competition in the context of mastering the material in the pesantren. doing amaliah ubudiyah yaumiyah, muraja'ah, discussion, and mukhafadzah is one way to achieve goodness. If this fastabiq al-khairat is carried out in bad ways, then al-khairat itself will lose its meaning. One of the principles that must be upheld in fastabiq al-khairat is that the attitude of acknowledging the truth or potential goodness of other parties. In this case, appreciation for the goodness or potential and strengths of other parties will increase cooperation and social harmony One of the principles that must be upheld in fastabiq al-khairat is that of acknowledging the truth or potential goodness of other parties. In this case, appreciation for the goodness or potential and strengths of other parties will increase cooperation and social harmony One of the principles that must be upheld in fastabiq alkhairat is that the attitude of acknowledging the truth or potential goodness of other parties. In this case, appreciation for the goodness or potential and strengths of other parties will increase 
cooperation and social harmony [4]. This is a great social capital for the sustainability of religious social life, maintaining community stability and tolerance. Therefore, the legality and competence of pesantren need more attention so that the graduates of the pesantren can spread and serve in various lines of life with various professions and competencies.

Not all students in the boarding schools will become kyai (religious experts), said $\mathrm{KH}$. Abdul Wahid Hasyim, Gus Dur's father, son of Hadratus Syaih Hasyim Asy'ari. Therefore, it is necessary to give lessons in Al-Jabar (Mathematics), History, Earth Sciences, Dutch and skills as a provision in his future life. This is one of the thoughts on the establishment of Madrasah Nidzamiyah at Pesantren Tebuireng around the 1930s which was initiated by Kyai A. Wahid Hasyim with Kyai Ilyas. Although for the context at that time many kyai opposed it, but with the blessing of Hadratus Syaih KH. Hasyim Asy'ari, the idea of including general lessons into Islamic boarding schools through Madrasah Nidzamiyah is gradually being realized. In the current context, The Indonesian Ministry of Religion through the Directorate General of Islamic Religious Institutions (now the Directorate General of Islamic Education) has collaborated with a number of well-known universities in Indonesia, through the Scholarship Program for Students with Achievement (PBSB). This is an effort to answer the stigma of learning in Islamic boarding schools "only studying religion (tafaqquh fiddin)", and less concerned with fulfilling other life needs [5]. This effort was carried out by the Ministry of Religion starting in 2005.

Some time ago, it was reported that the Directorate General of Islamic Education (Ditjen Pendis) of the Ministry of Religion would provide recognition or recognition of the equality of salafiyah pesantren education graduates with formal education. The mechanism is regulated in the Decree of the Director General of Islamic Education Number 4831 of 2018 concerning Recognition of Pesantren Graduates through Equality Examinations. As for the technical implementation of the equivalence test, it will be carried out once a year, together with the courses at the pesantren. Salafiyah pesantren santri who have completed the learning process at every level / level of education and have Kasyfu al-darajat or a certificate such as a certificate are welcome to take this exam [6]. This news is certainly a breath of fresh air for the Salafy Islamic boarding school. This recognition illustrates the opening up of opportunities for santri resources to enter higher education institutions and the niches of life or other institutions are increasingly wide open.

Followed later in 2019 the Government passed Law Number 18 of 2019 concerning Pesantren. With this Law, Pesantren throughout Indonesia have the same opportunity as other education in gaining State recognition as education that is equivalent to other education. However, in the local realm, local government and community intervention is no less important in realizing the ideals of the pesantren which have dimensions of education, preaching and community empowerment. Because Islamic boarding schools are educational institutions that have uniqueness according to their respective regions, the local government and local communities better understand the formula for supporting and developing pesantren in their regions. Therefore this article focuses on local government and society in implementing Law no. 18 of 2019 concerning Pesantren in Tegal Regency.

\section{Study Object}

As the object of the study of this article are Pesantren in Tegal Regency. Pesantren as institutions for religious education and religious education also have social, political dimensions and the existence of the Pesantren Law has a juridical dimension to be proposed as 
an object of research. Of course the pesantren is not alone, the community and local government are inseparable parts of the study of this article.

\section{Methodology}

This article is based on field research carried out with interviews, observations, documentation of pesantren life in Tegal Regency and literature study of laws and regulations related to religious and religious education and pesantren education. Islamic boarding school education in Tegal Regency that has been running for a long time and is close to the community by comparing it with the Pesantren Law and Regional Regulations related to pesantren is analyzed from a philosophical, sociological and juridical perspective.

\section{Results and Discussion}

Sociologist Peter L Berger, the world — including Tegal District — is leading to religiofication or desecularization. For him, the world is also on the way to integrating religious symbols or religious interpretations into the recesses of human civilization. The presence of religious symbols and institutions and their interpretations confirms that religion has become thicker in politics. The symptoms presented by Berger do not only run in the center of power nationally, but have penetrated into the local dimension, sub-power at the district level. It shows rebellion against an authoritarian system. Society wants to get out of the totalitarianistic system of government and make society helpless [7]. Thus the community wants an ideal society that is effective in accommodating its interests in this case is religion. Religion must formally become an integral part of state life, written normatively in a legalistic frame in the local realm. It is not surprising that some regions are sometimes offside in formulating regional regulations characterized by or based on religion.

The district of Tegal may be an ideal example of state-religion relations in the local realm. In 2017, Tegal Regency passed Regional Regulation Number 7 of 2017 concerning Religious Education. This Regional Regulation can be read as state intervention in religious life in Tegal Regency. From this regulation, it appears that the Tegal Regency Government has facilitated all religions in Tegal Regency in the realm of education. However, this Regional Regulation does not have sufficient coverage to cover pesantren, which are actually the seeds of all kinds of Islamic religious education. Many Pesantren in Tegal Regency face serious problems as the mother of Islamic religious education which has received a legal basis from the local government. We can briefly mention two problems faced by pesantren; external and internal.

\subsection{Pesantren external problems}

Zaki Mubarok and Mohammad Koidin in their research entitled Kiai Desa Keeping Pancasila; Cultural Moderation and Defense in 2018 which made Tegal Regency the object of research explained that the challenges faced by the Kiai (and their pesantren) from the outside are Authoritarianism and Populism [8]. First, religious authoritarianism is a challenge for pesantren. The moderate attitude of pesantren and kiai which has been the basis for maintaining the sovereignty of the State in the local realm with various models of education, preaching and community service by the authoritarian attitude of the 'new santri' is a job that is not based on sharia. New santri who download knowledge from social media often think the 
village kiai is wrong and should support the religious state or NKRI Bersyariah. The accumulated reproduction of these claims is the authoritarian attitude accepted by kiai and pesantren. Pesantren, which have been implementing akhlakul karimah education, gentle preaching and empowerment with subtle and societal bases, have recently increasingly faced religious authoritarianism from those who have just studied religion.

Second, populism which serves as a mobilization strategy adopted by political figures by creating enemies and perceiving themselves as figures. Hefner, Director of the Institute on Culture, Religion, and World Affairs (CURA), explained that populism destroys the culture, values and institutions of society that have a spirit of living together. The creation of the enemy is also in order to make the politician a figure. Without having a strong mass base, based on the creation of that enemy, he is shown to be a new figure. Populism creates tensions between civil society. The tension was created through baseless news. The creation of this enemy finds its momentum in the realm of electoral democracy, where politicians move through social media to influence the public to antagonize anyone who does not share the same opinion as the politician. The cultural identity of the kiai is muzzled in such a way as to be replaced with new subjects that are religious but in line with the political map that these politicians want. Global to local political contestation has made pesantren that are persistent in defending the ideology of the State using political channels which are often framed as enemies of civilization, left behind, rustic and have no vision of the future.

\subsection{Pesantren Internal Problems}

A field study regarding the dynamics of pesantren in Tegal Regency which shows several problems in the implementation of pesantren education in Tegal Regency needs to be presented as an effort to explain the concrete conditions of pesantren in Tegal Regency.

First, limited funding. The majority of Pesantren and their education are initiated or built by Kiai, clerics, individuals and organizations independently. The call to practice the knowledge that has been previously obtained at the Islamic boarding school where the Kiai learns makes them with all kinds of efforts to establish a boarding school. Sometimes it seems desperate, not accompanied by adequate cash flow. This is also what makes a Kiai in a boarding school in addition to playing a role as an educator, he also acts as a development manager or foreman. Not infrequently, we have to make every effort to find bailout funds to cover the operational costs of the pesantren. Although on the other hand it can also be seen that some Kiai have wide access to download aid from the government, however, this number is not proportional to the total number of Islamic boarding schools in Tegal Regency. This condition also causes a 'gap' / distance between one pesantren with easy access to assistance and a boarding school that is managed properly.

Second, educators and education personnel have not yet reached the competency standard. This classic problem begins with the absence of educational standards for educators and education personnel. For example, an educator often acts as an educational staff which of course breaks his concentration as an educator. Or vice versa. Although not all pesantren face this problem, standardization is important for the division of authority between educators and education staff so that each one concentrates on his part and has a clear output of his job. This division of authority will also be a reference for conducting satisfaction studies or job evaluations of each.

Third, inadequate facilities and infrastructure. Some pesantren still rely on donations from the santri guardians, the community and also private efforts to support the development or fulfillment of facilities and infrastructure. For example, by selling calendars to the public or 
alumni of pesantren. Although there is no quantitative data that states the effectiveness of selling calendars for the construction or fulfillment of Islamic boarding school infrastructure facilities, this effort is commonly carried out by pesantren. In addition, the energy, costs and thoughts of the students are involved in this calendar sales activity which is carried out by going around from one house to another. This is an important note for the management of pesantren.

Fourth, the developed curriculum has not been optimal. The Pesantren Law mandates that the curriculum is prepared based on the uniqueness of each Islamic boarding school. Thus, the authority in compiling and developing the curriculum is absolutely in the hands of pesantren. Optimizing the curriculum is the next agenda by, for example, presenting a community council across boarding schools and involving academics so that pesantren must not only be based on memorization aspects but also on practicum.

Fifth, the unavailability of vocational education which is expected to support the pesantren while in the community. An equally important note is the abstinence of vocational education in pesantren which equips prospective pesantren alumni when returning home or actualizing in the community. Often the alumni of pesantren are stuttered by reality. One hand must put his knowledge into practice, but on the other hand it is burdened economically, work. So it is not uncommon to find alumni of pesantren who have to work hard to become traders of fried rice or migrate to other cities and tend to be ignorant of their scientific development.

The external and internal problems of pesantren in Tegal Regency, when referring to the pesantren Law and the concurrent principle, are an integral part of the achievement of the vision and mission of Tegal Regency. Because the vision and mission of Tegal Regency is the guide of planning, implementation, evaluation and achievement of community development in Tegal Regency in a spiritual material. In simple terms it can be described in the following table:

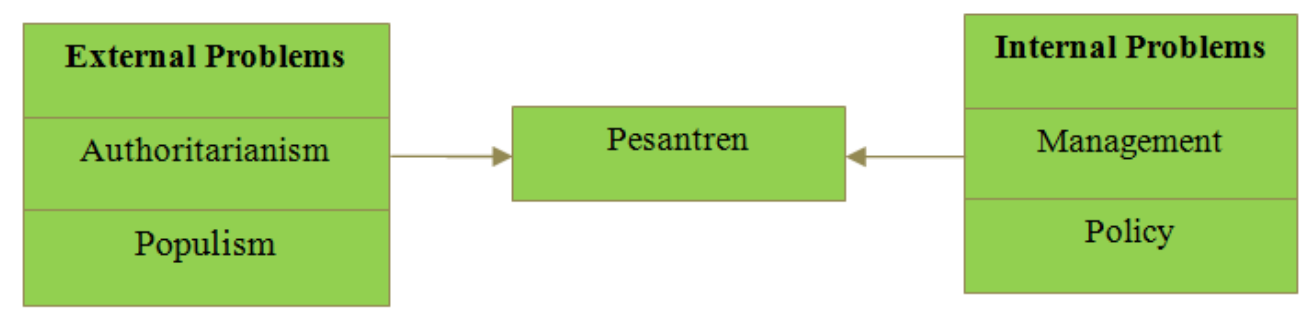

Fig 1. External and Internal Problems Pesantren

\subsection{Pesantren in the Vision and Mission of Tegal Regency}

Tegal Regency, in its vision states: The realization of a Tegal Regency Community that is Prosperous, Independent, Superior, Cultured, and has Noble Morals. While the mission states:

a. Realizing a government that is clean, open, accountable, and effective in serving the people.

b. Strengthening competitiveness through the development of reliable, quality, integrated and environmentally friendly infrastructure.

c. Building a people's economy that is strong, advanced, just and sustainable.

d. Improving the quality of human resources through strengthening education, health and social services by taking advantage of advances in science and technology.

e. Creating an orderly, safe, peaceful and comfortable community life while maintaining 
and preserving cultural values and local wisdom.

In the vision of Tegal Regency, it is clear that the term noble character is part of a series of welfare, independence, excellence and community culture. This shows that not only material aspects are the needs of the people of Tegal Regency, but no less important are spiritual ones which are shown by noble morals. In this logic, pesantren which function as educational institutions, preaching and community empowerment play an important role as an instrument to achieve this. Of course together with other educational institutions.

This vision is then strengthened in the mission of Tegal Regency in the form of improving the quality of human resources through education. Apart from that, it was also inscribed with a mission to preserve local / local wisdom. This is where pesantren with scientific tools has the potential to increase roles and achievements that have been proven to be able to adapt to local wisdom so that pesantren education is more productive in creating human resources who are not only intelligent but have a social vision and have noble character. In the Law on Pesantren Chapter I, Article 1 of the General Stipulation, it is explained that pesantren education is education that is organized by the pesantren and is within the pesantren by developing a curriculum in accordance with the peculiarities of the Pesantren based on the yellow book, based on Islamic books with muallimin education patterns, or other integrated forms. with general education.

Table 1. An Overview of the Position of Pesantren Education [9]

\begin{tabular}{|c|c|c|c|c|c|c|c|c|c|c|}
\hline \multirow{5}{*}{ 玄 } & \multicolumn{10}{|c|}{ JENIS PENDIDIKAN } \\
\hline & \multirow{3}{*}{\multicolumn{2}{|c|}{$\begin{array}{c}\text { PENDIDIKAN UMUM } \\
\text { FORMAL }\end{array}$}} & \multirow{2}{*}{\multicolumn{4}{|c|}{$\begin{array}{l}\text { PENDIDIKAN PESANTREN } \\
\text { JALUR PENDIDIKAN }\end{array}$}} & \multicolumn{4}{|c|}{ PENDIDIKAN KEAGAMAAN ISLAM } \\
\hline & & & & & & & \multirow{2}{*}{\multicolumn{3}{|c|}{ NON FORMAL }} & \multirow{3}{*}{\begin{tabular}{|l} 
INFORMAL \\
$\begin{array}{l}\text { Keluarga dan } \\
\text { Lingkungan }\end{array}$ \\
\end{tabular}} \\
\hline & & & \multirow{2}{*}{\multicolumn{3}{|c|}{$\begin{array}{l}\text { Pendidikan Muadalah, Pendidikan Diniyah } \\
\text { Formal dan Ma'had Aly }\end{array}$}} & \multirow[b]{2}{*}{$\begin{array}{c}\text { NON FORMAL } \\
\begin{array}{c}\text { Pesantren } \\
\text { hanya Mengaji }\end{array}\end{array}$} & & & & \\
\hline & $\begin{array}{c}\text { Sekolah dan } \\
\text { Perguruan } \\
\text { Tinggi Umum }\end{array}$ & $\begin{array}{c}\text { Madrasah dan } \\
\text { Pergururn } \\
\text { Tinggi } \\
\text { Keagamaan } \\
\text { Islam } \\
\end{array}$ & & & & & \multicolumn{3}{|c|}{$\begin{array}{l}\text { Madrasah Diniyah Takmiliyah, Pendidikan } \\
\text { Alqur'an dan Majelis Taklim }\end{array}$} & \\
\hline ড⿹弋巳 & $\begin{array}{c}\text { Perguruan } \\
\text { Tinggi Umum }\end{array}$ & $\begin{array}{c}\text { Perguruan } \\
\text { Tinggi } \\
\text { Keagamaan } \\
\text { Islam } \\
\end{array}$ & \multicolumn{3}{|c|}{ Ma'had Aly } & \multirow{5}{*}{ 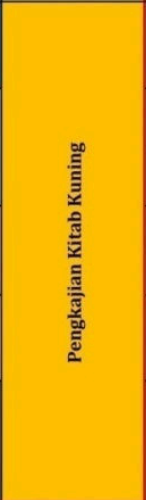 } & $\begin{array}{c}\text { Madrasah } \\
\text { Diniyah } \\
\text { Takmilyah } \\
\text { al-famiah }\end{array}$ & \multirow{3}{*}{$\begin{array}{c}\text { Pendidikan } \\
\text { Tahfidz Al- } \\
\text { Quran dan } \\
\text { Ta'limul Qur'an } \\
\text { lil Aulad }\end{array}$} & \multirow{5}{*}{$\begin{array}{l}\text { Majelis } \\
\text { Taklim }\end{array}$} & \multirow{5}{*}{$\begin{array}{l}\text { Keluarga dan } \\
\text { Lingkungan }\end{array}$} \\
\hline \multirow{3}{*}{ 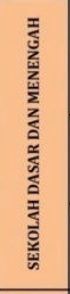 } & $\begin{array}{c}\text { Sekolah } \\
\text { Menengah } \\
\text { Atas/Sekolah } \\
\text { Menengah } \\
\text { Kejuruan } \\
\end{array}$ & $\begin{array}{c}\text { Madrasah } \\
\text { Aliyah/Madrasa } \\
\text { h Aliyah } \\
\text { Kejuruan }\end{array}$ & $\begin{array}{l}\text { Pendidikan } \\
\text { Muadalah } \\
\text { Ulya }\end{array}$ & \multirow{2}{*}{$\begin{array}{c}\text { Pendidikan } \\
\text { Muadalah } \\
\text { Wustha dan } \\
\text { Ulya secara } \\
\text { Berkesinamb } \\
\text { ungan }\end{array}$} & $\begin{array}{c}\text { Pendidikan } \\
\text { Diniyah Formal } \\
\text { Ulya }\end{array}$ & & $\begin{array}{c}\text { Madrasah } \\
\text { Diniyah } \\
\text { Takmiliyah } \\
\text { Ulya }\end{array}$ & & & \\
\hline & $\begin{array}{c}\text { Sekolah } \\
\text { Menengah } \\
\text { Pertama }\end{array}$ & $\begin{array}{l}\text { Madrasah } \\
\text { Tsanawiyah }\end{array}$ & $\begin{array}{l}\text { Pendidikan } \\
\text { Muadalah } \\
\text { Wustha }\end{array}$ & & $\begin{array}{c}\text { Pedidikan } \\
\text { Diniyah Formal } \\
\text { Wustha }\end{array}$ & & $\begin{array}{c}\text { Madrasah } \\
\text { Diniyah } \\
\text { Takmilyah } \\
\text { Wustha } \\
\end{array}$ & & & \\
\hline & Sekolah Dasar & $\begin{array}{l}\text { Madrasah } \\
\text { Ibtidaiyah }\end{array}$ & \multicolumn{2}{|c|}{ Pendidikan Muadalah Ula } & $\begin{array}{c}\text { Pendidikan } \\
\text { Diniyah Formal } \\
\text { Ula }\end{array}$ & & \begin{tabular}{|c|} 
Madrasah \\
Diniyah \\
Takmiliyah \\
Ula
\end{tabular} & $\begin{array}{c}\text { Taman } \\
\text { Pendidikan Al- } \\
\text { Quran }\end{array}$ & & \\
\hline 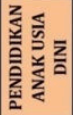 & $\begin{array}{c}\text { Taman Kanak- } \\
\text { kanak }\end{array}$ & Raudlatul Athfal & & & & & & $\begin{array}{l}\text { Taman Kanak- } \\
\text { kanak Al-Qur'an }\end{array}$ & & \\
\hline
\end{tabular}

From the Pesantren Law, it is clear that the equal status of pesantren education with general education, from both the muadalah ula education and the formal diniyah education to Ma'had Aly and the yellow book recitation. All of them are types and levels of education that are integrated into the national education system. Returning to the concurrent principle in sharing the obligations of the central, provincial and regional governments, it is time for the Tegal Regency Government to increase its formal legality in facilitating pesantren education.

In accordance with the mandate of the constitution, the state and government are obliged to guarantee and protect the rights of every citizen to embrace a religion and worship according to their religion, choose education and teaching, and provide facilities and services to fulfill 
the basic rights of these citizens, including through diniyah education and pesantren form of effort to give recognition, affirmation, and facilitation for its development.

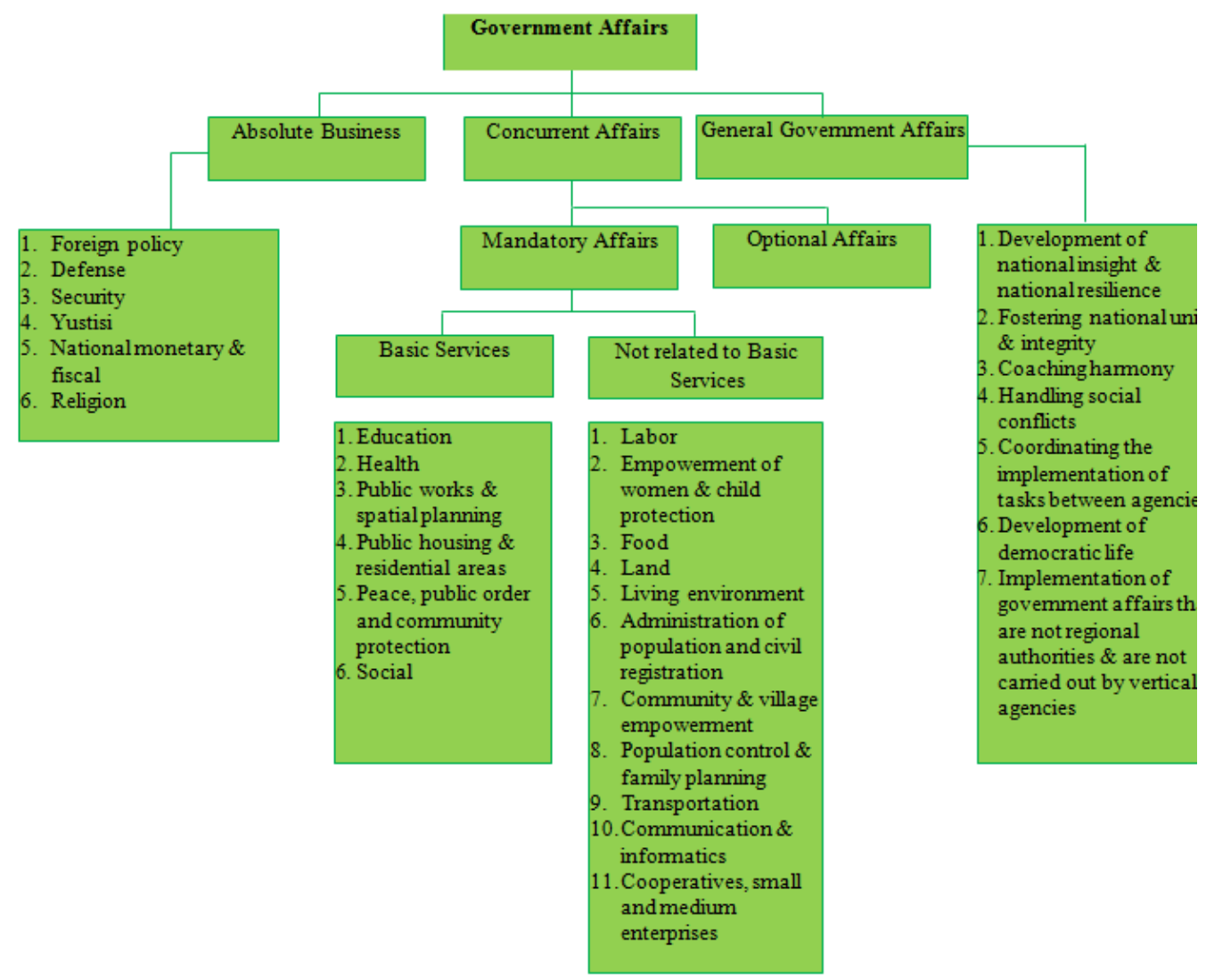

Fig 2. Gonverment Affairs

Authority or authority in the Big Indonesian Dictionary (KBBI) is defined as the right and power that is owned to do something [10]. In the case of state administration, authority is the whole rule derived from governmental organization law, which can be explained as rules relating to the acquisition and use of governmental powers by public legal subjects in public legal relations [11]. Regional governments have authority in the field of education as a consequence of regional autonomy. including in this case is religious and religious education as well as pesantren education.

In the context of Tegal Regency, it is necessary to reaffirm Diniyah education and Pesantren education are two different entities with their respective strengths, weaknesses and characteristics. Efforts to give recognition (recognition), affirmation and facilitation to diniyah and pondok pesantren education need to be based on an understanding of the distinctions based on their different characteristics between the two. Diniyah's education, in general, is one step better in obtaining local government facilities with Perda No. 7 of 2017 concerning religious education, while pesantren education, although the Pesantren Law has been passed, 
in the realm of Tegal Regency there is no Regional Regulation on Pesantren.

In the normative logic of the pesantren law and regional regulations on religious education in Tegal Regency, diniyah education is a term used to describe the type of Islamic religious education, to distinguish it from religious education with other religions. Several types of diniyah education can be mentioned here. Among others, Madrasah Diniyah Takmiliyah (MDT) and Al-qur'an Education Park (TPQ). What distinguishes it from pesantren education is that students in the MDT and TPQ programs are formal education students and want to deepen their religious knowledge outside the formal education curriculum that they follow. Thus, MDT and TPQ are non-formal education that goes together with formal education that students participate in. Both are held in a non-tiered or tiered manner, starting from early childhood education to tertiary education. MDT aims to complement Islamic religious education obtained by schools / madrasas or in higher education in order to increase the faith and devotion of students to Allah SWT.

MDT and TPQ can be organized by Islamic boarding schools, mosque administrators, managers of formal and non-formal education, Islamic community organizations, and other Islamic socio-religious institutions. MDT and TPQ can be held in mosques, mushalla, classrooms, or other learning spaces that meet the requirements. So far, the Tegal Regency government based on the Tegal Regency Regional Regulation Number 7 of 2017 concerning Religious Education has provided Islamic religious education facilitation to Madrasah Diniyah in the form of teacher incentives, facilities and infrastructure and BOP. Strictly speaking, based on Chapter VII Article 28 paragraph 4: Regional Government is obliged to provide the cost of providing religious education in accordance with statutory provisions.

Data in the Diniyah Education and Pesantren section of the Ministry of Religion, Tegal Regency, shows that the number of existing pesantren is almost evenly distributed in every district. This fact can also be interpreted as an educational, social, political and economic entity that is geographically capable of being a strategic partner of the regional government in running the wheels of government with the scientific implementation of the pesantren. As a strategic partner, in addition to carrying out the educational function, it also carries out a political function in the sense of participating in maintaining community stability, empowering the community, influencing the community to obey and be loyal to the state ideology and so on. Although on the other hand, pesantren are also still experiencing some lack of facilities and infrastructure to support the above functions.

Table 2. Data for Pesantren in Tegal Regency

\begin{tabular}{|c|c|c|c|c|}
\hline No. & NSPP / No Statistics & institution name & Address & Number of Santri \\
\hline 1 & 510333280004 & Attauhidiyyah & Kaligayam-Talang & 4950 \\
\hline 2 & 510033280003 & $\begin{array}{l}\text { Attauhidiyyah Saikh Armia Bin } \\
\text { Kurdi }\end{array}$ & Cikura-Bojong & 1144 \\
\hline 3 & 510333280044 & Attholibiyah Muncanglarang & Muncanglarang-Bumijawa & 1116 \\
\hline 4 & 510333280016 & Dar Al Qur’ An Al Islamy & Lebaksiu Kidul-Lebaksiu & 1357 \\
\hline 5 & 510033280002 & Ma'hadut Tholabah Putra & Jatimulya-Lebaksiu & 633 \\
\hline 6 & 510033280001 & Ma'hadut Tholabah Putri & Jatimulya-Lebaksiu & 529 \\
\hline 7 & 510033280107 & Tarbiyatut Tholibin & Batumirah-Bumijawa & 550 \\
\hline 8 & 510033280028 & Darul Mujahadah & North Prupuk-Margasari & 501 \\
\hline 9 & 510033280106 & Al Huda Manshurin & Dampyak-Kramat & 500 \\
\hline 10 & 510033280038 & Al Amin & Bulakwaru-Tarub & 549 \\
\hline 11 & 510033280048 & Mambaul Hikmah & Tegalwangi-Talang & 465 \\
\hline 12 & 510333280033 & Ribath Nurul Hidayah & Bedug-Pangkah & 357 \\
\hline 13 & 510333280046 & Al Ihsan Kabunan & Kabunan-Dukuhwaru & 339 \\
\hline 14 & 510033280005 & Misbahul Huda Al Amiriyah & Kambangan-Lebaksiu & 410 \\
\hline 15 & 510033280097 & Al-Qur'an Zaenuddin & Maribaya-Kramat & 406 \\
\hline 16 & 510033280063 & Hasyim Asy'ari & Karangjati-Tarub & 403 \\
\hline 17 & 510033280093 & Muhammadiyah Ahmad Dahlan & $\begin{array}{l}\text { Harjawinangun- } \\
\text { Balapulang }\end{array}$ & 382 \\
\hline
\end{tabular}




\begin{tabular}{|c|c|c|c|c|}
\hline No. & NSPP / No Statistics & institution name & Address & Number of Santri \\
\hline 18 & 510333280067 & Riyadus Sholihin & Karangmangu-Tarub & 223 \\
\hline 19 & 510033280084 & Al Adalah & Padasari-Jatinegara & 304 \\
\hline 20 & 510033280073 & Darul Khair & Jatimulya-Lebaksiu & 250 \\
\hline 21 & 510033280010 & Darussalam & Kalibakung-Balapulang & 294 \\
\hline 22 & 510033280006 & Nurul Hikmah & Tuwel-Bojong & 462 \\
\hline 23 & 510033280021 & Al Fajar & Jatimulya-Lebaksiu & 135 \\
\hline 24 & 510033280112 & Al Mush-Haf & kalisoka-Dukuhwaru & 214 \\
\hline 25 & 510033280024 & Tarbiyatul Mubtadiin & Danawarih-Balapulang & 180 \\
\hline 26 & 510333280007 & Miftahul Mubtadiin & Yamansari-Lebaksiu & 110 \\
\hline 27 & 510033280023 & Al Qur`An Al Hikmah & Dukuhlo-Lebaksiu & 49 \\
\hline 28 & 510033280110 & Al Fatkhu & Lebakgowah-Lebaksiu & 136 \\
\hline 29 & 510033280100 & Dzikrul Ghofilin Al Hasyimiyyah & Danawarih-Balapulang & 149 \\
\hline 30 & 510033280101 & Tahfidzul Qur`An Al Hasyimiyyah & Danawarih-Balapulang & 130 \\
\hline 31 & 510033280138 & Hufadzil Qur'an Darussakinah & Kalimati-Adiwerna & 141 \\
\hline 32 & 510033280026 & Daaru Ulil Albaab & Kedungkelor-Warurejo & 120 \\
\hline 33 & 510033280113 & Al Imam An Nawawi & Batuagung-Balapulang & 140 \\
\hline 34 & 510033280015 & Nurul Huda Al Muawanah & Danawarih-Balapulang & 141 \\
\hline 35 & 510033280075 & Tahfidzul Qur`An Salsabila & Tuwel-Bojong & 125 \\
\hline 36 & 510033280111 & Nuha's ironwood & Kalisapu-Slawi & 111 \\
\hline 37 & 510033280096 & Nurul Amin Al Ghozali & Lengkong-Bojong & 129 \\
\hline 38 & 510033280032 & Al Rizqi & Jatimulya-Lebaksiu & 107 \\
\hline 39 & 510033280102 & Dar Al-Faradis & Adiwerna-Adiwerna & 97 \\
\hline 40 & 510033280061 & Sunan Kalijaga Adiwerna & Kaliwadas-Adiwerna & 61 \\
\hline 41 & 510033280091 & Tahfid Darussalam & Kalibakung-Balapulang & 132 \\
\hline 42 & 510033280105 & Nurul Ikhsan & Handling-step control & 77 \\
\hline 43 & 510033280095 & An Nur & Kalisapu-Slawi & 70 \\
\hline 44 & 510033280114 & PP Tahfidzul Qur'an Al Amin & KUPU-Dukuhturi & 63 \\
\hline 45 & 510033280020 & Miftahul Huda & Kajen-Talang & 59 \\
\hline 46 & 510033280094 & At-Tin & Marga Ayu-Margasari & 58 \\
\hline 47 & 510033280103 & Al Anwar & $\begin{array}{l}\text { Harjawinangun- } \\
\text { Balapulang }\end{array}$ & 93 \\
\hline 48 & 510033280099 & As-Saifi Pancasila Sakti & Lebakgowah-Lebaksiu & 50 \\
\hline 49 & 510033280052 & Nu Miftahul Ulum & Margasari-Margasari & 123 \\
\hline 50 & 510033280086 & Nurul Huda Al Hasyimiyyah Putri & Danawarih-Balapulang & 24 \\
\hline 51 & 510333280037 & Al-Ma`Muriyah Darussalam & Jatimulya-Surodadi & 145 \\
\hline 52 & 510033280011 & Nurul Huda Al Hasyimiyyah Putra & Danawarih-Balapulang & 39 \\
\hline 53 & 510033280060 & Darul Muttaqin & Bukateja-Balapulang & 120 \\
\hline 54 & 510033280014 & Al-Falaah & Grobog Wetan-Pangkah & 35 \\
\hline 55 & 510033280104 & Al Aziz & Kajen-Talang & 33 \\
\hline 56 & 510033280115 & Al Ma'shumiyah & Karanganyar-Pagerbarang & 57 \\
\hline 57 & 512332809049 & Miftahul Jannah & Grobog kulon-Pangkah & 20 \\
\hline 58 & 512332818053 & Tahfidzul Quran Al Quthubi & Banjarturi-Warureja & 20 \\
\hline 59 & 510333280054 & Roudlotut Tholabah & Karangwuluh-Suradadi & 20 \\
\hline 60 & 510033280071 & Al Abror & Yamansari-Lebaksiu & 142 \\
\hline 61 & 512332802041 & Miftahul Huda Al-Mukhlasiyyah & Cempaka-Bumijawa & 38 \\
\hline 62 & 512332802038 & Mafatihul Huda Al Ihsani & Pagerkasih-Bumijawa & 102 \\
\hline 63 & 510033280057 & Ma'had Arrifa Tegal & Lebakgowah-Lebaksiu & 103 \\
\hline 64 & 510033280058 & Raudlatul Jannah & Cerih-Jatinegara & 107 \\
\hline
\end{tabular}

The data above are Islamic boarding schools which periodically submit reports to the Ministry of Religion to be organized in EMIS. In fact, the number of Islamic boarding schools in Tegal Regency is approximately 178. This means that there are still pesantren that are not administratively detected for the purposes of implementing local government policies related to Islamic boarding schools. Whereas referring to the Pesantren Law, the explanation regarding Pesantren, Dayah, Surau, Meunasah, or other names, hereinafter referred to as Pesantren are community-based institutions established by individuals, foundations, Islamic community organizations, and / or the community. who instills faith and piety in Allah SWT. Further explanation regarding pesanteran education is as follows:

a. Pesantren education is education that is organized by Islamic boarding schools and is located in the pesantren environment by developing a curriculum in accordance with the peculiarities of the pesantren based on the yellow book, based on Islamic books, with muallimin education patterns, or other forms integrated with general education. 
b. Kitab Kuning is an Islamic book in Arabic or any other language Islamic book that is a reference for Islamic scientific traditions in Islamic boarding schools.

c. Dirasah Islamiah with the Muallimin Education Pattern is a structured, systematic, and organized collection of studies on Islamic religious knowledge.

d. Another form that is integrated with general education is the study of the Yellow Book or the Islamic book which is integrated with the implementation of learning in madrasas or schools.

e. Pengkajian Kitab Kuning is Islamic boarding school education which is organized in the non-formal education path, which makes the Yellow Book the main reference in learning.

f. Muadalah education is Islamic boarding school education which is organized in the formal education pathway by developing a curriculum in accordance with the peculiarities of a boarding school based on the Yellow Book or Dirasah Islamiah with a tiered and structured Muallimin Education Pattern.

g. Formal Diniyah Education is Islamic boarding school education which is held in the formal education pathway in accordance with the peculiarities of the Pesantren based on the Yellow Book in a tiered and structured manner.

h. Ma'had Aly is a higher education boarding school organized by Islamic boarding schools and within the boarding schools by developing Islamic studies in accordance with the peculiarities of the Pesantren based on the Yellow Book in a tiered and structured manner.

Referring to the types of pesantren education, Tegal Regency has sufficient potential in achieving the vision and mission of Tegal Regency. Therefore support in the form of regional regulations regarding pesantren, for example, is very relational to the potential, mechanisms and achievement of the vision and mission of Tegal Regency. With the existence of a regional regulation on pesantren education, it is hoped that local governments will become more authoritative and stronger in facilitating, advocating, developing and administering education, preaching and empowering the community by Islamic boarding schools. It is also hoped that with this regional regulation the regional government will support, assist in licensing the birth of new pesantren education from various levels and encourage pesantren to be more orderly in administration. In addition, in Tegal Regency,

Narrative data can be conveyed from the Islamic boarding schools in Tegal Regency. This data refers to the Diniyah Education Section and Pesantren of the Ministry of Religion, Tegal Regency. In Kabuten Tegal, there are 64 pesantren with three types of educational patterns and their specifics. Among others, 25 Salafis, 6 Modern, 32 Combinations. The pesantren are cared for by 171 caretakers (81 Kiai and 37 Nyai). The total number of Ustadz or teachers of Islamic boarding schools in Tegal Regency is 1462 with a composition of 900 Ustadz and 530 Ustadzah. While the educational qualifications of ustadz are $864 \mathrm{Ustadz} / \mathrm{ustadzah}<\mathrm{S} 1,452$ Ustadz / Ustadzah S1 and 43 Ustadz / Ustadzah $\geq$ S2.

The number of santri in Tegal Regency reaches 20022 with a gender composition of 9754 male and 9926 female. The age range of santri for pesantren in Tegal Regency includes; age 13 years / SD totaled 2017, Age 16 Years / SMP amounted to 8605, Age 19 years / Senior high school totaled 5260 and graduated age amounted to 3500. In terms of facilities and infrastructure for pesantren in Tegal Regency, the data that can be presented are as follows; There are 853 dormitories with 'Good' quality, 160 lightly damaged, 31 buildings heavily damaged. The total number of pesantren dormitories in Tegal Regency is 1015. Meanwhile, the students' study rooms for Islamic boarding schools are 643 with details of 577 buildings, 44 lightly damaged and 16 heavily damaged. The total number of study rooms for Islamic 
boarding school students is 643 buildings.

So far, pesantren that provide Islamic religious education have received grants from the local government in the form of incentives, facilities and infrastructure under the legal of Regional Regulation Number 7 of 2017 concerning religious education. This legal provides more protection for Islamic religious education, namely Madrasah diniyah takmiliyah. If observed, the portion of grants for Islamic boarding schools, which are educational, preaching and community empowerment institutions, does not appear to be maximal and is still general in nature for its internal allocation of pesantren.

Comparison between Local Government Social Assistance to Islamic Religious Education for MDT teacher incentives channeled through the Diniyah Takmiliyah Communication Forum (FKDT), TPQ Teachers through the TPQ Coordinating Board (Badko), grants to MDT and TPQ with grants received by Islamic boarding schools show a very significant gap . This gap can be interpreted as an achievement for Islamic religious education, especially MDT and TPQ in Tegal Regency, on the one hand, but on the other hand it also leaves work to be done to facilitate the education of pesantren which has lagged far behind in terms of funding from the local government. As an illustration, here is a comparison of social assistance funds and grants received by Islamic religious education with Islamic boarding schools. This comparison is based on the reasons for the intersection of educational activities but differs in terms of regulation.

Table 3. MDT and TPQ Pondok Pesantren

\begin{tabular}{cccc}
\hline Year & MDT & TPQ & PONDOK PESANTREN \\
\hline 2019 & $6,365,000,000$ & $6,809,000,000$ & $450,000,000$ \\
2020 & $2,466,600,000$ & $2,505,350,000$ & $500,000,000$ \\
TOTAL & $\mathbf{8 , 8 3 1 , 6 0 0 , 0 0 0}$ & $\mathbf{9 , 3 1 4 , 3 5 0 , 0 0 0}$ & $\mathbf{9 5 0 , 0 0 0 , 0 0 0}$ \\
\hline
\end{tabular}

At the funding level, there is a serious disparity between social assistance and MDT-TPQ grants and Pesantren. Pesantren Law which was passed on October 15, 2019, is a milestone for pesantren throughout Indonesia. This law also makes all local governments responsible for ensuring the implementation of pesantren education in their respective regions. This includes providing equality in the budget for pesantren education along with other education according to regional strengths or abilities. Therefore, in this context, local governments must provide a legal basis for pesantren by issuing regional regulations on Islamic boarding schools.

\subsection{Discussion Result}

The urgency of Law Number 18 of 2019 concerning Pesantren at times requires regulatory instruments in the local sphere. None other than an effort to reach specific niches of Islamic boarding schools and local communities. So that Law Number 18 of 2019 has a regulative foothold in the local realm and its benefits can immediately be felt for Pesantren. Several grounds that can be put forward for the importance of regional regulations on pesantren include;

\section{a) Philosophical Basis}

Pondok Pesantren is actually a manifestation of a philosophical foundation that refers to the first precepts of the nation's philosophy (Pancasila), namely, God Almighty. Pesantren have existed from the beginning as an institution that forges their students to submit only to God Almighty. God Almighty is not interpreted as alien and far from human civilization in 
Indonesia. But God is always present in everyday human life. Pancasila as the nation's philosophy has faith and devotion to God Almighty where all kinds of human laws are subject to God's law. Pesantren education is an instrument that can be used to manifest forms of submission to God Almighty. Because God wants humans to always benefit others,

Pesantren Education as religious elements are also a form of freedom to embrace and carry out their respective religious services as their implementation is guaranteed in the 1945 Constitution of the Republic of Indonesia. Article 29 which states that the State is based on the One Godhead and the state guarantees the independence of each citizen to embrace their respective religions and to worship according to their religion and beliefs. Thus, the State is obliged to guarantee the implementation of religious life including Pesantren.

Table 4. Percentage of Population by District and Religion in Tegal Regency, 2018

\begin{tabular}{|c|c|c|c|c|c|c|c|}
\hline & districts & Islam & Protestant & Catholic & Hindu & Buddha & Others \\
\hline 010 & Margasari & 99.55 & 0.29 & 0.10 & 0.01 & 0.05 & 0.00 \\
\hline 020 & Bumijawa & 99.98 & 0.01 & 0.01 & 0.00 & 0.00 & 0.00 \\
\hline 030 & Bojong & 99.99 & 0.01 & 0.00 & 0.00 & 0.00 & 0.00 \\
\hline 040 & Race back & 99.80 & 0.11 & 0.07 & 0.00 & 0.02 & 0.00 \\
\hline 050 & Pagerbarang & 99.98 & 0.00 & 0.02 & 0.00 & 0.00 & 0.00 \\
\hline 060 & Lebaksiu & 99.96 & 0.00 & 0.03 & 0.01 & 0.00 & 0.00 \\
\hline 070 & Jatinegara & 100.00 & 0.00 & 0.00 & 0.00 & 0.00 & 0.00 \\
\hline 080 & Kedungbanteng & 99.84 & 0.06 & 0.08 & 0.02 & 0.00 & 0.00 \\
\hline 090 & Step & 99.64 & 0.18 & 0.17 & 0.00 & 0.01 & 0.00 \\
\hline 100 & Slawi & 95.62 & 1.55 & 1.45 & 0.62 & 0.48 & 0.28 \\
\hline 110 & Dukuhwaru & 99.86 & 0.02 & 0.07 & 0.02 & 0.03 & 0.00 \\
\hline 120 & Adiwerna & 99.28 & 0.63 & 0.06 & 0.01 & 0.02 & 0.00 \\
\hline 130 & Dukuhturi & 99.89 & 0.05 & 0.05 & 0.00 & 0.01 & 0.00 \\
\hline 140 & Gutter & 99.62 & 0.22 & 0.16 & 0.00 & 0.00 & 0.00 \\
\hline 150 & Tarub & 99.95 & 0.03 & 0.00 & 0.00 & 0.02 & 0.00 \\
\hline 160 & Kramat & 97.65 & 0.67 & 1.29 & 0.20 & 0.14 & 0.05 \\
\hline 170 & Suradadi & 99.96 & 0.03 & 0.01 & 0.00 & 0.00 & 0.00 \\
\hline 180 & Warureja & 99.89 & 0.09 & 0.02 & 0.00 & 0.00 & 0.00 \\
\hline
\end{tabular}

In the local realm, the number of Muslim population and the number of Pesantren as mentioned above, is part of the potential in achieving the vision and mission of the Tegal district that does not separate material and spiritual achievements in its development. Humans need spiritual fulfillment, communication or dialogue with the Almighty. More than that, humans also need beauty and aesthetics. Humans also need the mastery of certain skills so that they can work, both to fulfill their own interests and those of others. All these needs must be met in a balanced manner. Part of it cannot be fulfilled by leaving other needs behind. Humans are not only intelligent and skilled, but superficial in spirituality. Vice versa, it is not enough that a person has spiritual depth, but does not have certain intelligence and skills or expertise. So humans are completely compound with the basic principles of forming the identity and character of the best people (mabadi 'khaira ummah): QS. Ali Imran: 110 [12].

The most basic instrument for developing a whole human being is ensuring that every citizen has the right to education. Education, which has so far emphasized the realm of cognition (knowledge), must be changed through balancing knowledge with attitudes and skills. This has the aim of making education capable of giving birth to an intelligent and moral generation. The concept of character education by prioritizing morality in the delivery of education is character education based on local traditions and localities of religious teachings, 
capable of providing life lessons that are useful for the process of developing one's maturity through the educational process [13].

Pesantren education is an answer to the heterogeneity of society in Indonesia and in Tegal Regency in particular. This is because pesantren education has been accustomed to teaching differences as something to be feared or hostile to. On the other hand, differences, both internal and external, are different religions as a necessity that must be accepted with love. The difference in the curriculum that takes place at the Islamic boarding school proves this. Although one pesantren has different curricula and other differences, pesantren are able to create synergy between Islamic boarding schools to maintain peace and obey the state constitution. This is why Islamic boarding schools should get attention on par with other education.

\section{b) Sociological Basis}

In line with the dynamics of national and state life, in 2019 Law Number 18 of 2019 concerning Pesantren was born. However, this law requires legal instruments in the local sphere to support and implement the mandate of the constitution. Necessityit is not without foundation. Law No. 32/2004 on regional government and 33/2004 on the balance of central and regional finance are the juridical basis that affirms that regional autonomy has become part of the national government system. Regional autonomy according to law is the right, authority and obligation of an autonomous region to regulate and manage government affairs and the interests of the local community in accordance with statutory regulations. An autonomous region is defined as a legal community unit that has territorial boundaries which is authorized to regulate and administer government affairs and the interests of the local community according to their own initiatives based on the aspirations of the community in the NKRI system. If we look closely, regional autonomy is explicitly a mandate of the 1945 Constitution which has subsequently been amended. In the Constitution, there is a legal recognition of the need for respect for the regions that the management of regional autonomy, which is then carried out by the regional government, recognizes that there are differences in regional character so that it requires different arrangements. The terms symmetric and asymmetric decentralization are applied to accommodate this diversity [14].

So as a whole local politics is how people think and manifest the achievement of common goals through the facilitation of political organizations or institutions that are reflected in the effectiveness of local governments. In fact, local politics develops and lives in the context and space of the political system. Thus there is an inseparable interaction between the dynamics of national politics, local politics, and the role of local governments in carrying out their duties [15]. On this side, Tegal Regency with 281 villages and 6 sub-districts has the same opportunity to receive services based on the local context. Although it does not refer to exact data on how many pesantren are in Tegal Regency, seeing the victory of Umi AzizahSabilillah Ardi which is fully supported by NU, which means that the pesantren is in it, it is only natural that attention should be increased to the pesantren podok. Both in quality and quantity. Of course this is not only based on the primordial spirit of the pesantren. The term hubbul wathon minal faith or love for the country which is a product of pesantren should be a reference or consideration when the state is facing an ideological crisis. Pesantren with all their independence have been proven to be at the forefront of protecting the sovereignty of the Republic of Indonesia. Islam that lives and develops in pesantren reflects the strengths and ideals of moderate societies who live in mutual respect in peace. This situation must be supported by the local political system so that ideological power is stronger. 
One of Ricklefs' findings is that Islamization in Java always involves the political power of the ruling regime. Regimes always have justified reasons through various existing legislative instruments to influence and even hegemony the Islamization process. With data obtained from a variety of primary and secondary literatures, interviews, censuses and surveys, this book examines how the Javanese Muslim community went through difficult times since the beginning of the spread of Islam, Dutch and Japanese colonialism, the period of independence, President Soekarno's chaotic government, President Soeharto's totalitarianism. , and contemporary democracy. One part of this book describes the birth of a type of "new santri" that is puritanical and takes place in pesantren with a different curriculum than before. Java is under siege by the Islamization of the "new santri" who ignore local culture, and even try to eliminate it.

The term "new santri" who ignores local culture and wants puritanism is a separate reminder for pesantren throughout Java, including Tegal Regency. The "new santri" found many forms. One thing that can be mentioned is two residents of Tegal Regency who were caught as terrorist suspects. Both are members of the Anshorut Tauhid congregation. This arrest shows the exposure to radicalism to terrorism has reached a serious point in Tegal Regency. It is in this part that the state should strengthen and develop pesantren as official educational institutions in carrying out state and religious orders.

\section{c) Juridical}

Law Number 18 of 2019 concerning Pesantren is a collective agreement involving parties representing the Pesantren community, each of which has validated the formulation of legal norms optimally in accordance with the characteristics and peculiarities of Pesantren. Pesantren are community-based institutions founded by individuals, foundations, Islamic community organizations and / or communities that instill faith and piety in Allah SWT., Cultivate noble morals, and uphold the teachings of Islam rahmatan lil'alamin which is reflected in an attitude of humility, tolerant, balanced, moderate, and other noble values of the Indonesian nation through education, Islamic preaching, exemplary, and community empowerment within the framework of the Unitary State of the Republic of Indonesia. Consequently, on a practical level,

The existence of Law number 18 of 2019 concerning Pesantren can be read as follows. First, this law is a form of state recognition of pesantren as community-based Islamic education institutions, da'wah institutions, and community empowerment institutions. Second, affirmation, articles which constitute state policy in order to facilitate pesantren to carry out the three functions of the institution. Third, the pesantren law makes pesantren facilitated by the state. The three points above also contain the growing expectations of the state and the expectations of many parties towards the big family of pondok pesantren. Fourth, the source of funding for pesantren, which has been sourced from the community, is affirmed that this law can come from the state budget and regional budgets in accordance with the state's financial capacity. From there it appears that there is an opportunity for local governments to take part in the implementation of pesantren. Law Number 18 of 2019 concerning Pesantren provides sufficient space for Regional Governments to be involved and take a role in developing and empowering pesantren education institutions.

In the Indonesian government regulation number 55 of 2007 chapter I Article I, it is explained that religious education and pesantren education is a collective agreement of parties representing Muslims, Christians, Catholics, Hindus, Buddhists and Konghuchu. All who agree have validated the formulation of legal norms optimally according to the characteristics 
of each religion. That way, religious education and diversity education serve to prepare students to become members of society who understand and practice the values of their religious teachings and or become experts in the science of religion.

With the promulgation of Law no. 22 of 1999 concerning Regional Government, there was a fundamental change in the relationship between the Regional Government and the Central Government. Almost all government authorities that previously (prior to the promulgation of the Law) were in the hands of the Central Government now transferred (delegated) to Regional Governments. This is what came to be known generally as the Regional Autonomy. Some call this the term Decentralization.

According to Article 7 of the Law, "Regional authority includes authority in all areas of government, except authority in the fields of foreign policy, defense and security, judiciary, monetary and fiscal, religion, as well as other fields of authority. Iii While the other fields referred to" include policies regarding national planning and control of national development at a macro level, financial balance funds, state administration systems and state economic institutions, development and empowerment of human resources, utilization of strategic natural resources and high technology, conservation and national standardization.

From the aforementioned article, it can be seen that only these five areas are not under the authority of the Regional Government. This means that the five areas remain under the authority of the Central Government. In general terms, the five fields are not decentralized (autonomous). Religion is included in the five areas whose authority is not devolved to the Regional Government. However, with the implementation of regional autonomy, it is hoped that regional progress in all fields will accelerate. Likewise with the problem of Religious Education and Pondok pesantren. With regional autonomy it is hoped that the development and direction of Religious Education and Pesantren Education in an area will be more in line with the hopes and aspirations of the religious community in that area. Of course this will make it easier for religious education and Pesantren in regions that have had to deal with the Central Government in Jakarta to develop religious institutions. Now, they have enough to deal with the local government on this issue.

\section{Conclusion}

Education is a basic right for all Indonesian people. Including pesantren education that has long been served by the Indonesian people. It must be admitted that so far the government's attention has experienced a dynamic cycle. From the beginning not paying attention, becoming increasingly attentive. This is evidenced by various regulations and finally laws accommodating pesantren. Law number 18 of 2019 is not only interpreted as a gift or gift for pesantren. On the other hand, this law should spur Islamic boarding schools to welcome the various facilities and accommodations provided by the State through this law. This includes the role of local governments, which should provide local regulations to accommodate the needs of pesantren. The jurdical reference is clear, Law no. 18 of 2019. The visionary work of local governments in accommodating pesantren education is an unforgettable condition. With regional regulations, the law on pesantren will immediately benefit pesantren, which means that the effectiveness of the government will run well. Because the measure of the effectiveness of a government (Vinus, 2011) is how people get services and how the quality of service includes the quality of public services that are free from political pressure, the quality of policy formulation, the quality of financial management, and the credibility of the government's commitment to the policies that have been set. Thus, the attributes of 
government effectiveness appear in the context of policy, human resource (HR) and financial management, as well as continuous improvement of the performance of policies and services implemented. Overall, the measurement of effectiveness can be done in the area of public perception and tangible results that can be proven physically (data or documents) are secondary. Essentially, the effectiveness of government is judged by the level of government capacity in responding to sensitive issues and crises in society.

\section{References}

[1] https://kemenag.go.id/berita/read/507095/kemenag-perkuat-moderasi-islam-melewatpesantren

[2] Muammar Ramadhan, "Deradicalization of Religion through Multicultural Education and Inclusivism (Studies at Pesantren al-Hikmah Benda Sirampog Brebes)", Journal of SMART (Study of Society, Religion and Tradition), Vol. 1, No. 2, 2015https://blasemarang.kemenag.go.id/journal/index.php/smart/article/view/250

[3] Mualimul Huda, The Existence of Islamic Boarding Schools and Deradicalization of Islamic Education in Indonesia (Sowing the Spirit of Tolerance and Multicultural Islamic Education), Focus Journal; Journal of Islamic and Social Studies Vol. 3, No. 1, 2018 P3M Curup State Islamic College (STAIN) Bengkuluhttp://journal.staincurup.ac.id/index.php/JF

[4] https://kumparan.com/ruchman-basori/dari-negara-untuk-pondok-pesantren-catatanrefleksi-12-tahun-pbsb-k Kementerian-agama-ri-1522078775975

[5] https://islami.co/ijazah-l Grad-pesantren-salafiyah-kini-bisa-setara-pend Pendidikanformal/

[6] Zaki Mubarok, Wayang Santri; Ngapak Discourse and Dimensions of Political Power, 2016, Elsa Press, Semarang,

[7] Deputy for Political, Legal, Defense and Security Affairs Ministry of National Development Planning / National Development Planning Agency, 2014. Local Politics Against the Effectiveness of Local Government, Research Report.

[8] e-Journal, Gus Dur's thoughts can be accessed from http: // www e-jurnal.com, December 21, 2017

[9] Al-Nashr M. Sofyan, Character education based on local wisdom: an analysis of KH. Abdurrahman Wahid.Scriptions, 2010, accessed from walisongo.ac.id

[10] MC Ricklefs, 2013, Islamizing Java; The History of the Islamization of Java and Its Opponents from 1930 to the Present, Serambi, Jakarta

[11] https://otomotif.antaranews.com/berita/733400/tiga-terduga-teroris-ditangkap-di-tegaldan-semarang

[12] This research was facilitated by the Directorate General of Islamic Higher Education at the Ministry of Religion through the 2018 Research and Community Service program.

[13] Law No. 18 of 2019 concerning Islamic Boarding Schools

[14] https://kbbi.kemdikbud.go.id/entri/kewayaan

[15] According to HD Stout in Ridwan HR, State administrative law, (Yogyakarta: UII Press, 2002) 
